\title{
A Platform to Understand Amyotrophic Lateral Sclerosis (ALS) and Extend Human Motor Neurons Longevity
}

\author{
Plataforma para Empezar a Comprender la Esclerosis Lateral Amiotrófica (ELA) \\ y Extender la Longevidad de Neuronas Motoras Humanas
}

Cáceres, D. E..$^{1,2}$; Torres, F. C..$^{1,2}$; Castillo, C. A. ${ }^{1,2}$; Maureira, A. ${ }^{1}$; Franco-Campos, F. A. ${ }^{1}$;

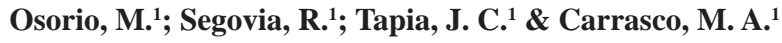

CÁCERES, D. E.; TORRES, F. C.; CASTILlo, C. A.; MAUREIRA, A.; FRANCO-CAMPOS, F. A.; OSORIO, M.; SEGOVIA, R. TAPIA, J. C. \& CARRASCO, M. A. A platform to understand amyotrophic lateral sclerosis (ALS) and extend human neurons longevity. Int. J. Morphol., 37(4):1203-1209, 2019.

SUMMARY: In vitro modeling of neurodegenerative diseases is now possible by using patient-derived induced pluripotent stem cells (iPS). Through them, it is nowadays conceivable to obtain human neurons and glia, and study diseases cellular and molecular mechanisms, an attribute that was previously unavailable to any human condition. Amyotrophic lateral sclerosis (ALS) is one of the diseases that has gained a rapid advance with iPS technology. By differentiating motor neurons from iPS cells of ALS- patients, we are studying the mechanisms underlying ALS- disease onset and progression. Here, we introduce a cellular platform to help maintain longevity of ALS iPS-motor neurons, a cellular feature relevant for most late-onset human diseases. Long term cultures of patient-derived iPS cells might prove to be critical for the development of personalized-drugs.

KEY WORDS: Motor neurons; Amyotrophic Lateral Sclerosis (ALS); Induced pluripotent stem cells (iPS); Glia.

\section{INTRODUCTION}

Human iPS development. A few years back (2007), Yamanaka and colleagues (Takahashi et al., 2007; Takahashi \& Yamanaka, 2006) made an unparalleled discovery. They found that four transcription factors (Oct4, Sox2, Klf4, and c-Myc) were sufficient for transforming already mature human cells into a class of cells that had the ability to generate others, i.e. pluripotent stem cells (Takahashi et al.; Takahashi \& Yamanaka). Such cells, induced pluripotent stem cells (iPS), were able to generate cells from all three germinal layers, but also they were able to renew themselves (Srivastava \& DeWitt, 2016; Takahashi et al.; Tapia \& Schöler, 2016; Yu et al., 2007). This technological advance made possible a multiplicity of medical and scientific avenues, from generating specific human cells for regenerative medicine to cells that could be used for studying a diversity of human diseases (Yu et al.; Zaehres \& Schöler, 2007), in particular cells from diseases that we know little about the causes or mechanisms.

Human iPS disease modelling. Most diseases are multifactorial, environmental or genetic (or both) factors must happen so the disease can be triggered. Thus many diseases are not hereditary but sporadic in nature, which means that may or may not be genetic in origin, making its study tremendously complex. Despite this, there are sporadic diseases in which it has been possible to generate successful iPS model cells to study them (Jung et al., 2012; Payne et al., 2015). An example is amyotrophic lateral sclerosis (ALS), a fatal neurodegenerative disorder that specifically affects spinal cord motor neurons which play a key role in motor function and respiration (Almeida et al., 2013; Guo et al., 2017; Lee \& Huang, 2017; Robberecht \& Philips, 2013). Most cases of ALS are sporadic in nature, which means there is no known cause or mechanism for the disease, and a small percentage of ALScases are associated with a known genetic mutation (C9orf72, SOD1, TARDBP, FUS, and ANG) (Freischmidt et al., 2017). Therefore, it is imperative to have human models for studying mechanisms responsible for the disease onset and progression, and also for seeking development of specific therapeutic approaches. The modelling of neurodegenerative disorders with iPS cells might overcome several disadvantages of animal based- protocols (Kehinde, 2013; Akhtar, 2015), and give novel insights to the fields of human development and neurological diseases.

\footnotetext{
${ }^{1}$ Department of Biomedical Sciences, Faculty of Health Sciences, Universidad de Talca, Talca, Chile.

${ }^{2}$ Neuroscience and Stem Cell Research Center (CICMN), Universidad de Talca, Talca, Chile.
} 
CÁCERES, D. E.; TORRES, F. C.; CASTILlO, C. A.; MAUREIRA, A.; FRANCO-CAMPOS, F. A.; OSORIO, M.; SEGOVIA, R. TAPIA, J. C. \& CARRASCO, M. A. A platform to understand amyotrophic lateral sclerosis (ALS) and extend human neurons longevity. Int. J. Morphol., 37(4):1203-1209, 2019.

ALS- human iPS motor neurons longevity. ALS disease is a late-onset disorder (Robberecht \& Philips). We and others have used iPS cells derived from patients to differentiate motor neurons ( Di Giorgio et al., 2007; Amoroso et al., 2013; Guo et al.; Lee \& Huang, 2017). However, it is unclear how well newly derived motor neurons from iPS model late-onset diseases, where patients takes 50 or more years to develop ALS- symptoms. The differentiation from human to immature cells yield embryonic-like cell types that often require significant time to mature to establish mature- like properties (Saha \& Jaenisch, 2009; Liu et al., 2012). Here, we present a technical development to extend the longevity of iPS derived motor neurons. Our advance is relevant to the study of ALS, but it can also be implemented to other late- onset diseases to address the role of age-associated factors.

\section{MATERIAL AND METHOD}

Mouse genetic models and derivation of glia. Mice were handled in accordance to the guidelines established by the bioethics committee of University of Talca, following approved protocols for the good care and use of laboratory animals. Transgenic mice (Jackson Laboratories, USA) were used at birth (P0) to generate glia monolayers. Mice were bred according to Jackson lab's protocols. Cortical tissue was isolated in calcium- and magnesium-free Hanks' BSS (HBSS). Under a dissecting microscope, tissue was isolated, cut into small pieces and transferred to $50 \mathrm{ml}$ centrifuge tube containing $12 \mathrm{ml}$ of HBSS. Tissue digestion was performed using trypsin-EDTA (GIBCO BRL no. 25200) and $1 \%$ DNAse (Sigma no.DN-25) at $37^{\circ} \mathrm{C}$ for $15 \mathrm{~min}$, swirling the mixture periodically. Dissociated tissue was triturated using a fire-polished Pasteur glass pipette and filtered through a 72-m nylon mesh (NITEX $100 \%$ polyamide nylon fiber, TETKO) to remove any undissociated tissue. Filtered material was pelleted at $300 \mathrm{~g}$ for $5 \mathrm{~min}$ and resuspended in $2 \mathrm{ml}$ of glia medium (minimum essential medium with Earl's salts, GIBCO BRL no.11095-080, $20 \%$ glucose, penicillin streptomycin, GIBCO BRL no.15145-014, and $10 \%$ horse serum, GIBCO BRL no.26050-070) and the cell number determined. Once confluent (generally in 10-14 d), cells were replated onto 12 well dishes coated with PDL (Sigma).

Culture of iPS lines and Differentiation to motor neurons. The iPS cells Control and ALS were maintained on gelatinized tissue-culture plastic on a monolayer of neomycin selected mouse embryonic fibroblasts (MEFs; Millipore) in hiPS media consisting of Dulbecco's Modified Eagle Medium: nutrient mixture F-12 (DMEM/F:12, Invitrogen) with $20 \%$ Knockout Serum Replacer (KSR; Invitrogen), $110 \mathrm{mM} \beta$-mercaptoethanol (BME; Sigma), L-Glutamine and nonessential amino acids (NEAA; Invitrogen), and 20 $\mathrm{ng} / \mathrm{ml}$ basic fibroblast growth factor (bFGF;Invitrogen). To generate motor neurons, undifferentiated iPS cells were incubated with $10 \mathrm{mM}$ Rho-associated kinase inhibitor Y27632 (Calbiochem) for $2 \mathrm{hr}$ and then passaged using trypsin, triturated, and placed into ultra-low adherent culture dishes (Corning) for the seeding of embryoid bodies (EBs). The first 11 days, the cells were kept in suspension in hiPS cell media without bFGF supplement. At day 11, EBs will be switched to neural induction medium (DMEM/F:12 with L-glutamine, NEAA, N2 supplement, Invitrogen). Then at day 12, EBs were incubated using retinoic acid (RA1mM, Sigma) and purmorphamine (PUR10mM, Calbiochem) and kept in induction for another 2 weeks. Finally, at day 28, EBs were dissociated with $0.05 \%$ papain (Wothington), electroporated with HB9 $(9 \mathrm{~Kb})$-promoter-GFP when needed using Lonza Nucleofector, and plated onto polyD-lysine/laminin coated (BD Biosciences) glass at $5 \mathrm{x}^{10} \mathrm{E} 5$ cells $/ \mathrm{ml}$. To prepare cells for live imaging, they were allowed to settle on glass coverslips that were flipped over primary glial monolayers to sustain neuronal development and maturity. Plated neurons were cultured in DMEM:F12 media supplemented with N2, B27 (Invitrogen), retinoic acid (Sigma), D-glucose and $40 \mathrm{ng} / \mathrm{ml}$ of BDNF, GDNF, CNTF and NT3. Media was changed every other day and all iPS derived motor neurons (iMNs) were kept for a period of 1-8 weeks.

Immunocytochemical experiments. Cells were fixed with $4 \%$ paraformaldehyde-PBS, blocked and permeabilized with BSA (1\%)-Triton X-100 (0.1\%). Then, they were incubated overnight with the following antibodies for survival studies: rabbit polyclonal anti- Neurofilament (Chemicon), and mouse anti-HB9 (Developmental Studies Hybridoma Bank University of Iowa). After several washes, cells were incubated with donkey antibodies specific for rabbit, conjugated to Cy3 $(1: 1000,2 \mathrm{~h})$, and/or donkey antibodies specific for mouse, conjugated to Cy 5 antibodies $(1: 1000,2 \mathrm{~h}$; Jackson ImmunoResearch). Samples were then mounted in Vectashield (Vector Labs), and confocal or epifluorescence microscopy was performed using LSM700 (Zeiss), equipped with 20, 40 and $60 \mathrm{X}$ oil immersion objective, 1.45 NA. Image acquisition was performed using Zen software (Zeiss). Offline analysis of relative intensities for all the samples were done using Metamorph 4.5 (Universal Imaging). Only cells having morphological features of neurons were considered for analysis. To analyze the pluripotency, characteristic of IPS colonies, we used the PSC 4-Marker Immunocytochemistry Kit (Nanog, Tra-160, SSEA-4 and Oct 3-4. Invitrogen Catalog Numbers A24881 and A25526).

Data analysis. Statistical analyses were performed using Student's t-test or ANOVA (OriginPro7, Microcal). Results 
CÁCERES, D. E.; TORRES, F. C.; CASTILlO, C. A.; MAUREIRA, A.; FRANCO-CAMPOS, F. A.; OSORIO, M.; SEGOVIA, R. TAPIA, J. C. \& CARRASCO, M. A. A platform to understand amyotrophic lateral sclerosis (ALS) and extend human neurons longevity. Int. J. Morphol., 37(4):1203-1209, 2019.

were expressed as mean \pm s.e.m.; t-test values of $* \mathrm{P}<0.05$, $* * \mathrm{P}<0.01, * * * \mathrm{P}<0.005$ was considered statistically significant. To reduce variability, experiments were performed in sister cultures.

\section{RESULTS}

Experimental design to culture human ALS- motor neurons for long periods of time. Our goal is to understand the mechanisms that trigger ALS disease. For this, we used human motor neurons derived from iPS cells. Typically, these cells do not survive for more than 14 days in vitro when cultured under traditional single cell culture. As we indicated earlier, ALS is a late onset disease, thus much of the phenotype is likely to be absent in 14 days of in vitro development. To overcome this limitation of the model, we developed a cellular methodology to lengthen the lifespan of ALS- motor neurons in vitro (Fig. 1). We first culture the iPS to form colonies for 3 days to a week, as soon as we have $60 \%$ of confluency we split the colonies and grow them in suspension to form embryonic bodies. These cellular formations were then treated with retinoic acid (RA) and purmorphamine (PUR) to induce caudalization and ventralization of pluripotent stem cells, here we are directing the fate of these stem cells into a motor neuron. Traditionally, motor neurons differentiated from neurospheres are plated on polystyrene petri dishes and survive at most for about fourteen days in vitro. To elongate the lifespan of the cells we first plated them on clean glass treated with a combination of laminine and poly-d-lysine, after these initial treatment we use drops of wax to form a tripod in the glass (see methods). This step is very useful if the motor neuron population is desired to be studied independently (Phatnani et al., 2013). In parallel, we prepared a culture of mouse or human glial cells when needed, which may or may not be ALS positive. Glial cells were then plated on glass and kept in vitro for 2 weeks until the cells reach confluency. After this period the motor neurons derived from IPSs are platted on the glass as previously described and flip over the confluent monolayer of Glia. This side to side "cellular sandwich", each cell not in physical contact with the other, allowed motor neurons to stay in vitro for over 2 months, something impossible to do without glial support.

From iPS to long-term cultures of motor neurons. Our iPSs cells have been characterized previously, skin biopsies from ALS patients were used to generate the iPSs cells (Bilican et al., 2013, 2012; Serio et al., 2013). To demonstrate pluripotency of iPSs a panel for trophic factor markers was used. As we expected, the iPS cells were positive for Nanog (Fig. 2 B), Tra-160 (Fig. 2 C), OCT3-4 (Fig. 2 D), and SSEA4 (Fig. 2 E). The pluripotency of the cells was confirmed by the teratoma formation assay, and the karyotypes remained stable in all passages used (Bilican et al.). The iPSs derived motor neurons (iMNs) were generated by using a chemical protocol (methods). We then plated iPS cell-derived motor neurons together with primary cortical glial cultures derived from wild type neonatal mice and cultured the cells for 3, 7, 14, 28 days

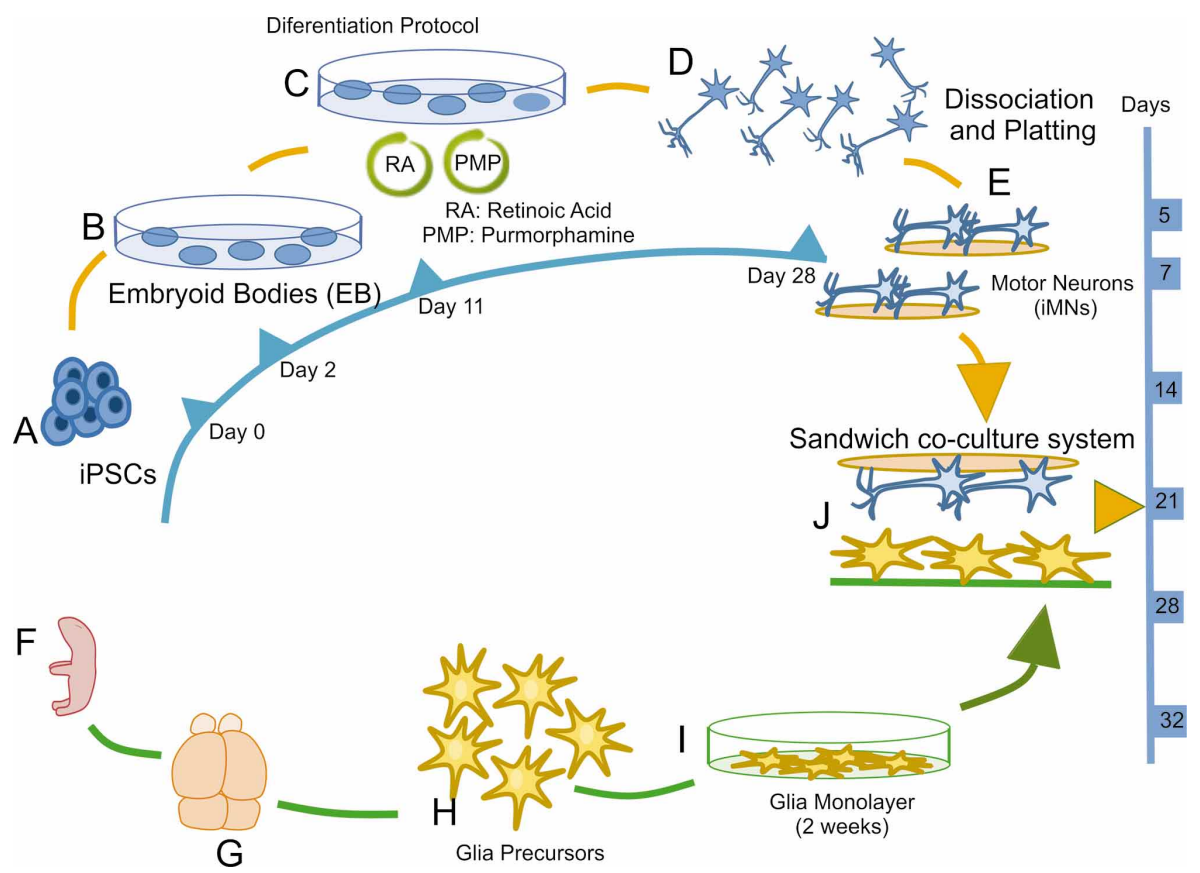

Fig. 1. A platform to model ALS in vitro Using human induced pluripotent stem cells from patients. The diagram shows a co-culture system, specially designed to study the interactions between neurons and Glia. We adapted this model from a commonly used technique to culture hippocampal neurons for long term. First, iPS cells were grown in colonies (A), later they were seeded in suspension to form embryoid bodies (B) and go through the differentiation protocol (C-E). After 4 weeks, human motor neurons were plated over glass coverslips previously treated (E) and flipped over Glia monolayers. In parallel, Glia monolayers were cultured from neonatal mouse (P0-P3) (F), using brain cortex $(\mathrm{G})$ to extract glial precursors $(\mathrm{H})$ that reached confluency at 2 weeks in vitro (i). The resulting sandwich coculture system is shown in (J). 
in vitro or longer (two months). Specifically, the iPSs- derived motor neurons were plated on glass coverslips coated with poly-d-lysine and laminin; and inverted over wells containing glial cells monolayers. Figure 3 shows representative phase contrast- images of human motor neurons grown in presence of glial cells ("cellular sandwich"). Motor neurons survived for long periods of time, from 5 days to more than 40 days, and some cases for 60 days in vitro. In general, cells at 21 days of age were showing morphological hallmarks of a mature neuron, including enlarge soma (i.e.> $15 \mu \mathrm{m}$ ) and depicted long neuronal processes, indicative of a healthy cellular environment.
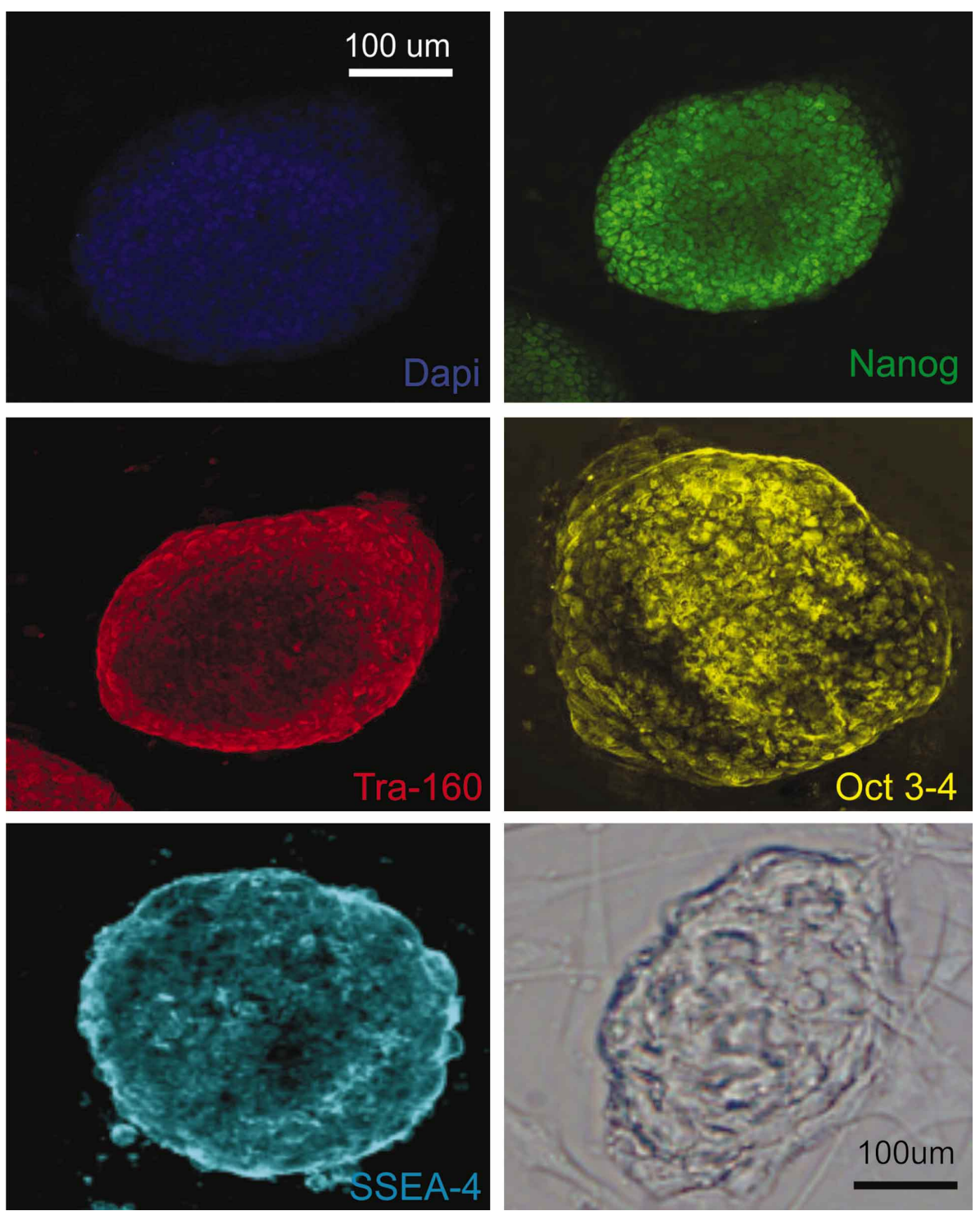

Fig. 2. Characterization of iPS derived from ALS patients. The images from A to F show IPs colonies with different pluripotency markers used to confirm IPs nature. A representative iPS colony with a nuclear stain DAPI is shown in A. IPs colonies were immunostained against Nanog (B), Tra-160 (C), Oct 3-4 (D), and SSEA-4 (E). A representative brightfield image of an iPS colony is shown in F. Scale bar $=100 \mu \mathrm{m}$.
The Sandwich approach to elongate the in vitro life of iPSmotor neurons. Since iPSs can also differentiate into other cell types (OLIG2+cells, etc), it is critical to use molecular markers to identify motor neurons. Here, the long term grown cells (sandwich of glial cells), were stained with two well known molecular markers, neurofilament (a classic neuronal marker) and HB9 (motor neuron specific marker). Figure 3 shows that differentiated cells (left panel, DAPI= blue, nuclear marker) were strongly labeled when an antibody against neurofilament (NFL) was used (Fig. 4; A, left panel, NF: red label). Irrespective of the in vitro age analyzed, a dense network of cellular processes was observed in all samples studied, a condition that demonstrates the healthy state of neurons grown on the sandwich format. To establish that neurons were indeed motor neurons, we used an antibody against HB9. As expected, more than $70 \%$ of the neurons (Fig. 4; $\mathrm{B}$, right panel, NF:red label) were also stained for HB9, a marker that labels the cell somata of only motor neurons (Figure 4; B, right panel, HB9: green label). Overall, we show that ALS- patient derived motor neurons can be maintained in vitro for more than 40 days.

\section{DISCUSSION}

It is evident that the phenotypes and classic hallmark pathologies are not fully represented in-vitro. The reasons for this are not really clear, but may be associated to the fact that neurons generated from iPS may be too young in the dish, compared to those present in patients with late onset diseases. We and others have showed evidence that iPSC-derived motor neurons can model early changes of ALS- disease, and thus prove the utility of the method to study disease mechanisms. If however, we want to characterize ALSclassic hallmarks in these cells, we find that many of them are not present in the cultures (i.e. amyloid plaques, neuronal 
A
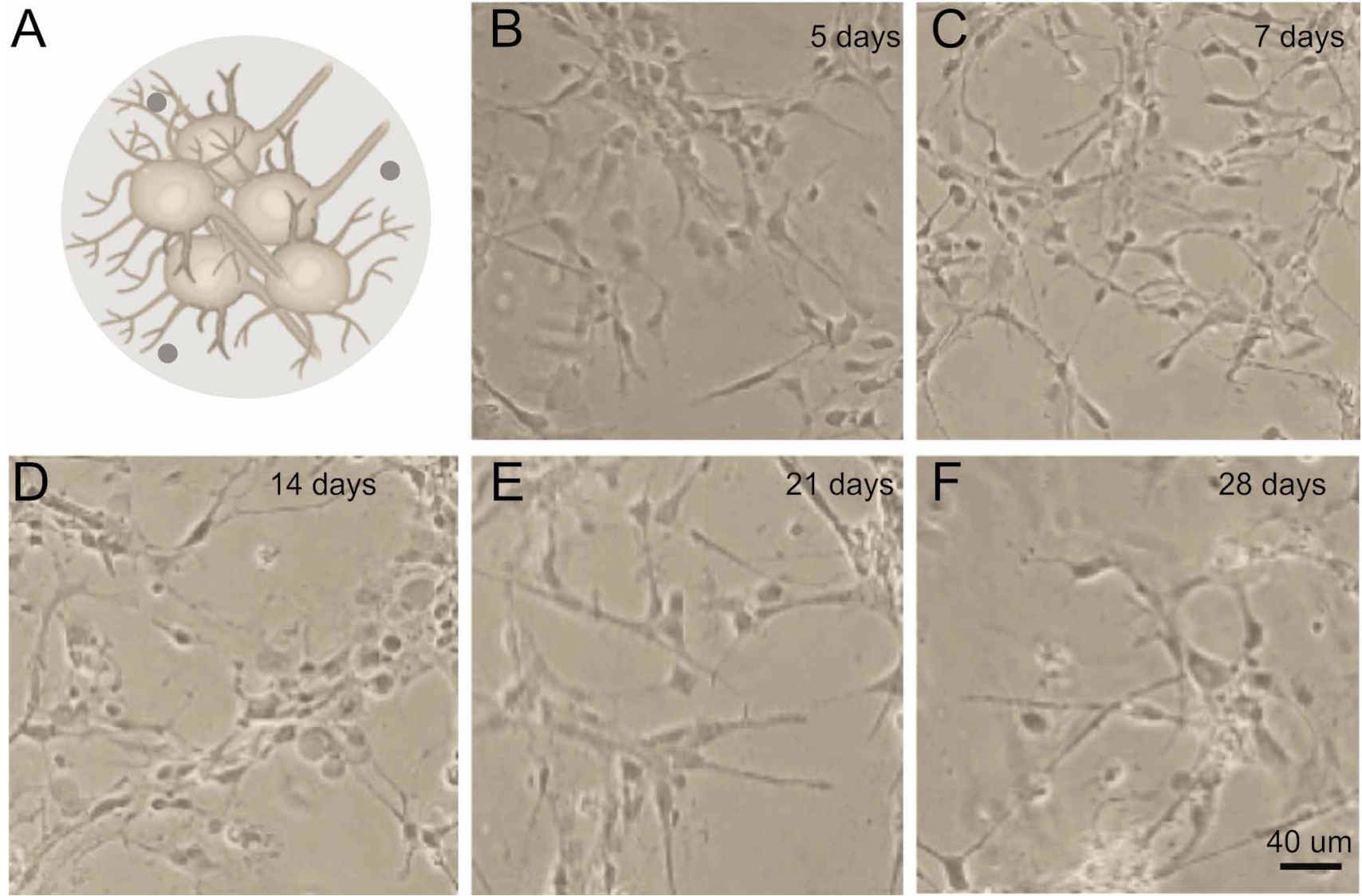

Fig. 3. Neurons derived from ALS patient can be co-cultured for up to 4 weeks in vitro. (A-F) show representative images of IPS derived motor neurons. Images in A, B,C,D and E show neurons cultivated for 5, 7, 14, 21 and 28 days respectively; F shows a diagram of the neurons as represented in Figure 1. Bright field images were acquired with a 20x objective, scale bars $=20 \mu \mathrm{m}$.
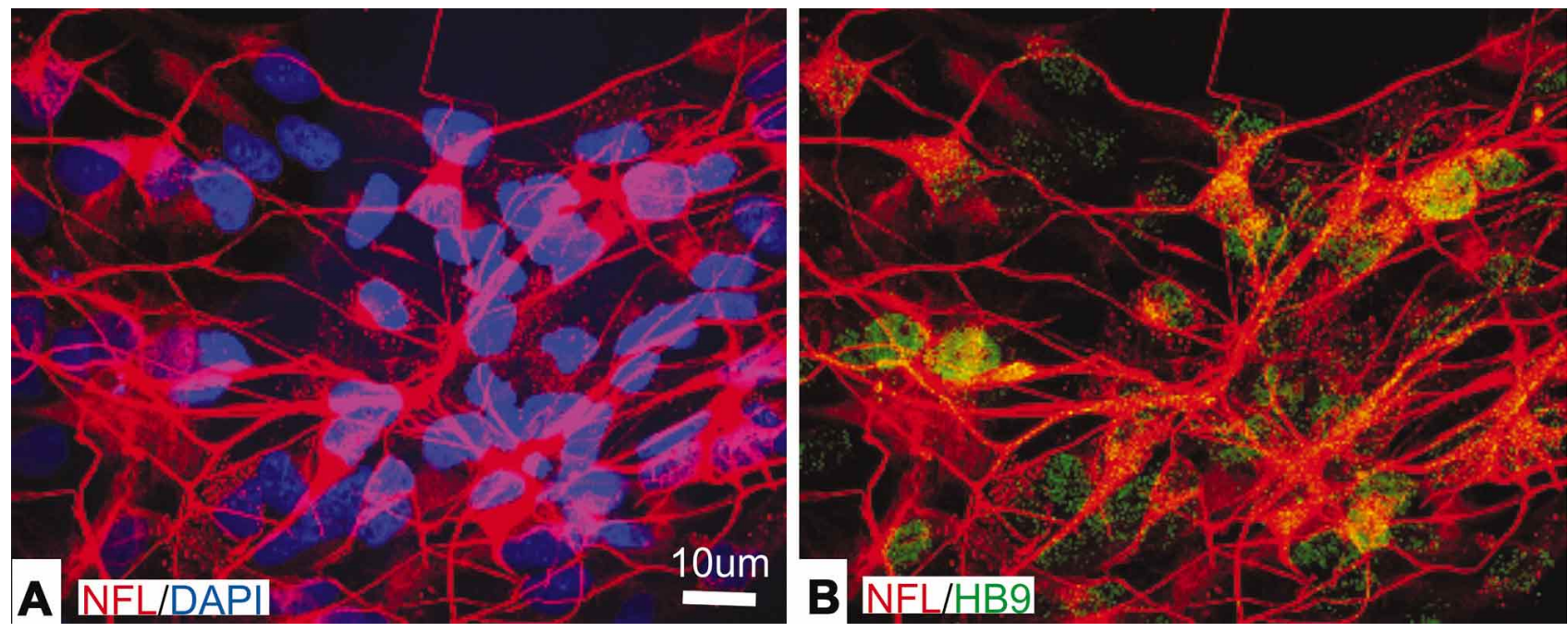

Fig. 4 Motor neurons derived from ALS patients and co-cultured for 2 weeks in vitro are a robust model for high throughput screening of new drugs or small molecules to treat ALS. The image shows iPS derived motor neurons from an ALS patient. Confocal images depicts in blue the nuclear stain, DAPI; in red, an antibody against Neurofilament ( $\mathrm{Rb}$, Thermofisher), and in green an antibody against HB9 (Mo), a motor neurons maker from Developmental hybridoma Bank Iowa. Images were acquired with a 40x NA1.2 immersion oil objective, scale bars $=10 \mu \mathrm{m}$. 
CÁCERES, D. E.; TORRES, F. C.; CASTILlO, C. A.; MAUREIRA, A.; FRANCO-CAMPOS, F. A.; OSORIO, M.; SEGOVIA, R. TAPIA, J. C. \& CARRASCO, M. A. A platform to understand amyotrophic lateral sclerosis (ALS) and extend human neurons longevity. Int. J. Morphol., 37(4):1203-1209, 2019.

fragments, cytoplasmic vesicular bodies). It might be that cultures need to be maintained for longer to fully represent a late onset disease, and thus by extending the lifespan of the cultures we might be able to reveal the pathological hallmark of patients in the in-vitro model. One approach to extend the life span of cells is presented here. We developed a cellular based approach to produce co-cultures of glial and human iPSmotor neurons; the iPS- motor neurons were plated on glass coverslips to face a monolayer of astrocytes. This "two-cells sandwich" was able to extend the life-span of human iPSmotor neurons for weeks to months. In general, motor neurons were more mature, they have a large cell body connected with an intricate network of processes, with distinctive physiological properties. The two cell types are maintained physically apart, although they share the same medium. Thus, factors secreted by one cell type likely impact on the health, survival, gene expression of the other, a process that we and others are very interested to analyze because molecules from cells in particular astrocytes might negatively interfere with the other cell. These non-cell autonomous interactions play a crucial role in several conditions of ALS disease development. Although, we use the two cells setup for ALS studies, the approach can be applied to PD, AD or FTD, all late- onset pathologies with particular phenotypes in the dish.

Future avenues. The co culture method offers the possibility for understanding the contribution of cell-autonomous and non-cell autonomous mechanisms to the ALS. We have used this setup for RNA sequencing individual cell types model to study molecular pathways specific to each cell type. Also, the long term cultures may be especially useful for drug screening, for studying for high-throughput drug and effector screens. Clearly, the use of long term cultures is a major improvement in our understanding of late onset neurodegeneration. Despite all, it is worth keeping in mind that the model might not fully represent the situation found in patients.

Our approach could also be used for growing cells for cellular therapies to treat diseases or injuries. Cellular replacement for neurodegenerative diseases involves the derivation of specific neuronal subtypes lost in disease and subsequent grafting into affected areas of the nervous system. The newly transplanted neurons may then integrate, synapse and recapitulate a neural network similar to the one lost in disease. Alternatively, stem cells may provide environmental enrichment to support host neurons by producing neurotrophic factors, scavenging toxic factors or creating auxiliary neural networks around affected areas. Many strategies for environmental enrichment utilize stem cells to provide de novo synthesis and delivery of neuroprotective growth factors at the site of disease. Growth factors such as glial-derived neurotrophic factor (GDNF), brain-derived neurotrophic factor (BDNF), insulin-like growth factor-I (IGF-I) and vascular endothelial growth factor (VEGF) are protective in neurodegenerative disease models and provide in situ support at the main foci of disease. The appropriate objective of cellular therapy for each neurodegenerative disease must be based on the specific neuronal pathology of each disorder. While cellular replacement may be effective in diseases like PD where a specific neuronal subpopulation is lost, ALS is most likely to benefit from cellular therapies that enrich the local spinal cord environment to support the remaining MNs. Factors such as how well grafted neurons integrate and migrate within the host tissue, and the distances that axons must extend to reach their targets, must be considered when determining the potential efficacy of cellular therapies for neurodegenerative diseases.

\section{CONCLUSION}

This sandwich co-culture model system is a valuable tool for studying cellular and molecular mechanisms between iPS- human derived motor neurons and glia in health and disease. The patient derived reprogramming of cells provides the opportunity to learn about pathological non-cell autonomous interactions. Furthermore, this simple tool might prove to be extraordinary for the development of new therapeutic strategies.

\section{ACKNOWLEDGMENTS}

We thank all the members of the CICMN for helpful discussions and technical assistance. We are very grateful to Professor Claudio Cruzat and Gonzalo Trujillo for their assistance during this work. We thank CMA, Core imaging facility at the University of Concepción and German Osorio for his kind help on image acquisition. We are also grateful to Tom Maniatis, Chris Shaw and Siddharthan Chandran for providing the IPs cells from ALS patient (Serio et al., 2013) (Alami et al., 2014; Bilican et al., 2012). Funding: This study was supported by the Fondo Nacional de Investigación y Ciencia (FONDECYT No. 1161014, MC, No. 1160888, JCT), Chile.

CÁCERES, D. E.; TORRES, F. C.; CASTILlO, C. A.; MAUREIRA, A.; FRANCO-CAMPOS, F. A.; OSORIO, M.; SEGOVIA, R. TAPIA, J. C. \& CARRASCO, M.A. Plataforma para empezar a comprender la esclerosis lateral amiotrófica (ELA) y extender la longevidad de neuronas motoras humanas. Int. J. Morphol., 37(4):1203-1209, 2019.

RESUMEN: Actualmente es posible modelar in vitro enfermedades neurodegenerativas humanas mediante el uso de células madre pluripotentes inducidas (iPS) derivadas del paciente. A través de 
ellas, es hoy concebible obtener neuronas y glía humanas, y estudiar mecanismos celulares y moleculares de enfermedades, un atributo que anteriormente no era posible para ninguna condición humana. La esclerosis lateral amiotrófica (ELA) es una de las enfermedades que se ha beneficiado con la tecnología de iPS. Al diferenciar neuronas motoras de células iPS obtenidas de pacientes con ELA, hemos iniciado estudios sobre los mecanismos que subyacen a la aparición y progresión de la enfermedad. Aquí, presentamos el desarrollo de una plataforma celular que permite extender la longevidad de las neuronas motoras derivadas de iPS, una característica relevante para la mayoría de las enfermedades humanas de inicio tardío. Los cultivos a largo plazo de células iPS provenientes de pacientes pueden ser determinantes en el desarrollo de terapias asociadas a la medicina de precisión.

PALABRAS CLAVE: Neuronas motoras; Esclerosis lateral amiotrófica (ALS); Células madre pluripotentes inducidas (iPS); Glia.

\section{REFERENCES}

Akhtar, A. The flaws and human harms of animal experimentation. Camb. $Q$. Healthc. Ethics, 24:407-19, 2015.

Alami, N. H.; Smith, R. B.; Carrasco, M. A.; Williams, L. A.; Winborn, C. S.; Han, S. S. W.; Kiskinis, E.; Winborn, B.; Freibaum, B. D.; Kanagaraj, A.; Clare, A. J.; Badders, N. M.; Bilican, B.; Chaum, E.; Chandran, S.; Shaw, C. E.; Eggan, K. C.; Maniatis, T. \& Taylor, J. P. Axonal transport of TDP-43 mRNA granules is impaired by ALS-causing mutations. Neuron, 81:536-43, 2014.

Almeida, S.; Gascon, E.; Tran, H.; Chou, H. J.; Gendron, T. F.; Degroot, S.; Tapper, A. R.; Sellier, C.; Charlet-Berguerand, N.; Karydas, A.; Seeley, W. W.; Boxer, A. L.; Petrucelli, L.; Miller, B. L. \& Gao, F. B. Modeling key pathological features of frontotemporal dementia with C9ORF72 repeat expansion in iPSC-derived human neurons. Acta Neuropathol., 126:38599, 2013.

Amoroso, M. W.; Croft, G. F.; Williams, D. J.; O'Keeffe, S.; Carrasco, M. A.; Davis, A. R.; Roybon, L.; Oakley, D. H.; Maniatis, T.; Henderson, C. E. \& Wichterle, H. Accelerated high-yield generation of limb-innervating motor neurons from human stem cells. J. Neurosci., 33:574-86, 2013.

Bilican, B.; Serio, A.; Barmada, S. J.; Nishimura, A. L.; Sullivan, G. J.; Carrasco, M.; Phatnani, H. P.; Puddifoot, C. A.; Story, D.; Fletcher, J.; Park, I. H.; Friedman, B. A.; Daley, G. Q.; Wyllie, D. J. A.; Hardingham, G. E.; Wilmut, I.; Finkbeiner, S.; Maniatis, T.; Shaw, C. E. \& Chandran, $\mathrm{S}$. Mutant induced pluripotent stem cell lines recapitulate aspects of TDP43 proteinopathies and reveal cell-specific vulnerability. Proc. Natl. Acad. Sci. USA, 109:5803-8, 2012.

Bilican, B.; Serio, A.; Barmada, S. J.; Nishimura, A. L.; Sullivan, G. J.; Carrasco, M.; Phatnani, H. P.; Puddifoot, C. A.; Story, D.; Fletcher, J.; Park, I. H.; Friedman, B. A.; Daley, G. Q.; Wyllie, D. J. A.; Hardingham, G. E.; Wilmut, I.; Finkbeiner, S.; Maniatis, T.; Shaw, C. E. \& Chandran, S. Comment on "Drug screening for ALS using patient-specific induced pluripotent stem cells". Sci. Transl. Med., 5:188le2, 2013.

Di Giorgio, F. P.; Carrasco, M. A.; Siao, M. C.; Maniatis, T. \& Eggan, K. Noncell autonomous effect of glia on motor neurons in an embryonic stem cell-based ALS model. Nat. Neurosci., 10:608-14, 2007.

Freischmidt, A.; Müller, K.; Ludolph, A. C.; Weishaupt, J. H. \& Andersen, P. M. Association of mutations in TBK1 with sporadic and familial amyotrophic lateral sclerosis and frontotemporal dementia. JAMA Neurol., 74:110-3, 2017

Guo, W.; Fumagalli, L.; Prior, R. \& Van Den Bosch, L. Current advances and limitations in modeling ALS/FTD in a dish using induced pluripotent stem cells. Front. Neurosci., 11:671, 2017.

Jung, Y. W.; Hysolli, E.; Kim, K.Y.; Tanaka, Y. \& Park, I. H. Human induced pluripotent stem cells and neurodegenerative disease: prospects for novel therapies. Curr. Opin. Neurol., 25:125-30, 2012.
Kehinde, E. O. They see a rat, we seek a cure for diseases: the current status of animal experimentation in medical practice. Med. Princ. Pract., 22:Suppl 1:52-61, 2013.

Lee, S. \& Huang, E. J. Modeling ALS and FTD with iPSC-derived neurons. Brain Res. 1656:88-97, 2017.

Liu, G. H.; Ding, Z. \& Izpisua Belmonte, J. C. iPSC technology to study human aging and aging-related disorders. Curr. Opin. Cell Biol., 24: 765 74, 2012.

Payne, N. L.; Sylvain, A.; O’Brien, C.; Herszfeld, D.; Sun, G. \& Bernard, C. C. A. Application of human induced pluripotent stem cells for modeling and treating neurodegenerative diseases. N. Biotechnol., 32: 212-28, 2015.

Phatnani, H. P.; Guarnieri, P.; Friedman, B. A.; Carrasco, M. A.; Muratet, M.; O’Keeffe, S.; Nwakeze, C.; Pauli-Behn, F.; Newberry, K. M.; Meadows, S. K.; Tapia, J. C.; Myers, R. M. \& Maniatis, T. Intricate interplay between astrocytes and motor neurons in ALS. Proc. Natl. Acad. Sci. USA, 110:E756-65, 2013

Robberecht, W. \& Philips, T. The changing scene of amyotrophic lateral sclerosis. Nat. Rev. Neurosci., 14:248-64, 2013.

Saha, K. \& Jaenisch, R. Technical challenges in using human induced pluripotent stem cells to model disease. Cell Stem Cell, 5:584-95, 2009.

Serio, A.; Bilican, B.; Barmada, S. J.; Ando, D. M.; Zhao, C.; Siller, R.; Burr, K.; Haghi, G.; Story, D.; Nishimura, A. L.; Carrasco, M. A.; Phatnani, H. P.; Shum, C.; Wilmut, I.; Maniatis, T.; Shaw, C. E.; Finkbeiner, S. \& Chandran, S. Astrocyte pathology and the absence of non-cell autonomy in an induced pluripotent stem cell model of TDP-43 proteinopathy. Proc. Natl. Acad. Sci. USA, 110:4697-702, 2013.

Srivastava, D. \& DeWitt, N. In vivo cellular reprogramming: the next generation. Cell, 166:1386-96, 2016.

Takahashi, K.; Tanabe, K.; Ohnuki, M.; Narita, M.; Ichisaka, T.; Tomoda, K. \& Yamanaka, S. Induction of pluripotent stem cells from adult human fibroblasts by defined factors. Cell, 131:861-72, 2007.

Takahashi, K. \& Yamanaka, S. Induction of pluripotent stem cells from mouse embryonic and adult fibroblast cultures by defined factors. Cell 126:66376, 2006.

Tapia, N. \& Schöler, H. R. Molecular Obstacles to Clinical Translation of iPSCs. Cell Stem Cell, 19:298-309, 2016.

Yu, J.; Vodyanik, M. A.; Smuga-Otto, K.; Antosiewicz-Bourget, J.; Frane, J. L.; Tian, S.; Nie, J.; Jonsdottir, G. A.; Ruotti, V.; Stewart, R.; Slukvin, I. I. $\&$ Thomson, J. A. Induced pluripotent stem cell lines derived from human somatic cells. Science, 318:1917-20, 2007.

Zaehres, H. \& Schöler, H. R. Induction of pluripotency: from mouse to human. Cell, 131:834-5, 2007.

Corresponding author:

Monica Carrasco Pastenes

Profesor Asociado

Departamento de Ciencias Básicas Biomédicas

Facultad de Ciencias de la Salud

Universidad de Talca

Avenida Lircay s/n. Talca 3460000

CHILE

Email: mocarrasco@utalca.cl

Received: 03-03-2019

Accepted: 07-05-2019 